\title{
Genetic parameters of different measures of cheese yield and milk nutrient recovery from an individual model cheese-manufacturing process
}

\author{
G. Bittante, C. Cipolat-Gotet, and A. Cecchinato ${ }^{1}$ \\ Department of Agronomy, Food, Natural Resources, Animals and Environment (DAFNAE), University of Padova, Viale dell'Università 16, \\ 35020 Legnaro (PD), Italy
}

\begin{abstract}
Cheese yield $(\mathrm{CY})$ is an important technological trait in the dairy industry, and the objective of this study was to estimate the genetic parameters of cheese yield in a dairy cattle population using an individual modelcheese production procedure. A total of 1,167 Brown Swiss cows belonging to 85 herds were sampled once (a maximum of 15 cows were sampled per herd on a single test day, 1 or 2 herds per week). From each cow, $1,500 \mathrm{~mL}$ of milk was processed according to the following steps: milk sampling and heating, culture addition, rennet addition, gelation-time recording, curd cutting, whey draining and sampling, wheel formation, pressing, salting in brine, weighing, and cheese sampling. The compositions of individual milk, whey, and curd samples were determined. Three measures of percentage cheese yield $(\% \mathrm{CY})$ were calculated: $\% \mathrm{CY}_{\mathrm{CURD}}, \% \mathrm{CY}_{\text {SOLIDS }}$, and $\% \mathrm{CY}_{\text {WATER }}$, which represented the ratios between the weight of fresh curd, the total solids of the curd, and the water content of the curd, respectively, and the weight of the milk processed. In addition, 3 measures of daily cheese yield ( $\mathrm{dCY}, \mathrm{kg} / \mathrm{d}$ ) were defined, considering the daily milk yield. Three measures of nutrient recovery (REC) were computed: $\mathrm{REC}_{\mathrm{FAT}}, \mathrm{REC}_{\mathrm{PROTEIN}}$, and $\mathrm{REC}_{\mathrm{SOLIDS}}$, which represented the ratio between the weights of the fat, protein, and total solids in the curd, respectively, and the corresponding nutrient in the milk. Energy recovery, $\mathrm{REC}_{\mathrm{ENERGY}}$, represented the energy content of the cheese versus that in the milk. For statistical analysis, a Bayesian animal model was implemented via Gibbs sampling. The effects of parity ( 1 to $\geq 4$ ), days in milk (6 classes), and laboratory vat (15 vats) were assigned flat priors; those of herdtest-date, animal, and residual were given Gaussian prior distributions. Intra-herd heritability estimates of $\% \mathrm{CY}_{\text {CURD }},{ }_{\%} \mathrm{CY}_{\text {SOLIDS }}$, and $\% \mathrm{CY}_{\text {WATER }}$ ranged from 0.224 to 0.267 ; these were larger than the estimates obtained for milk yield (0.182) and milk fat content (0.122), and
\end{abstract}

Received December 21, 2012.

Accepted July 29, 2013.

${ }^{1}$ Corresponding author: alessio.cecchinato@unipd.it similar to that for protein content (0.275). Daily cheese yields showed heritability estimates similar to those of daily milk yield. The trait $\% \mathrm{CY}_{\text {WATER }}$ showed a highly positive genetic correlation with $\% \mathrm{CY}_{\text {SOLIDS }}(0.87)$, whereas their phenotypic correlation was moderate (0.37), and the fat and protein contents of milk showed high genetic correlations with \%CY traits. The heritability estimates of $\mathrm{REC}_{\mathrm{PROTEIN}}$ and $\mathrm{REC}_{\mathrm{FAT}}$ were larger (0.490 and 0.208, respectively) than those obtained for the protein and fat contents of milk, and the genetic relationships between $\mathrm{REC}_{\mathrm{PROTEIN}}$ and $\mathrm{REC}_{\mathrm{FAT}}$ with milk protein and fat content were low or moderate; $\mathrm{REC}_{\text {PROTEIN }}$ and $\mathrm{REC}_{\mathrm{FAT}}$ were moderately correlated with the \% CY traits and highly correlated with $\mathrm{REC}_{\text {SOLIDS }}$ and $\mathrm{REC}_{\text {ENERGY }}$. Both $\mathrm{REC}_{\text {SOLIDS }}$ and $\mathrm{REC}_{\text {ENERGY }}$ were heritable $(0.274$ and 0.232$)$, and showed high correlations with each other (0.96) and with the \%CY traits (0.83 to 0.97). Together, these findings demonstrate the existence of economically important, genetically determined variability in cheese yield that does not depend solely upon the fat and protein contents of milk, but also relies on the ability of the coagulum to retain the highest possible proportions of the available protein, fat, and water. Exploitation of this interesting genetic variation does not seem to be feasible through direct measurement of the phenotype in cows at the population level. Instead, further research is warranted to examine possible means for indirect prediction, such as through assessing the midinfrared spectra of milk samples.

Key words: individual cheese yield, fat and protein recovery, whey loss, genetic parameter

\section{INTRODUCTION}

Cheese production is the most important use of milk produced in many countries (International Dairy Federation, 2011), and the technological parameter of percentage cheese yield (\% CY; the quantity of cheese obtained from a given quantity of milk processed, expressed as a percentage) is the most important economic trait for the dairy industry and, indirectly, for the definition of price of milk (Emmons, 1993). Nevertheless, 
no previous study has estimated genetic parameters of $\% \mathrm{CY}$ or its daily cheese yield (dCY; the quantity of cheese, in kilograms, obtained from milk yielded by a cow in $1 \mathrm{~d}$ ). This lack of knowledge can be attributed to 2 main issues: difficulties in individually measuring this trait on a large number of individuals, and the availability of phenotypically correlated traits for the indirect selection of cheese yield.

Cheese is traditionally obtained from the bulk milk of one or more herds. To obtain cheese yield measures at the level of individual animals, a model cheese-making procedure must be set up. This becomes labor intensive because of the many manual steps required, including individual milk sampling; milk analysis; milk weighing and heating; starter culture preparation and addition; $\mathrm{pH}$ measurement; rennet preparation and addition; gelation-time recording and curd cutting; whey drainage, sampling, weighing and analyses; curd sampling and analyses; wheel formation; compression; salting; and weighing (Cipolat-Gotet et al., 2013). Moreover, the smaller the volume of the model cheese, the less it represents conditions of industrial cheese-making.

The most important indirect traits used to improve cheese yield (\% CY and $\mathrm{dCY}$ ) are the milk contents of fat and protein (or casein). Almost all of the selection indices for dairy breeds around the world include milk fat and protein content ( $\mathrm{kg}$ or \%; VanRaden, 2004; Miglior et al., 2005). The relative weights of fat and protein contents within these selection indices are often based on the relative economic or technical importance of these 2 nutrients in the dairy industry (Weigel et al., 1997; Rosati and Van Vleck, 2002). The inclusions of fat and protein in the selection indices are based on the following implicit assumptions: (1) different proteins and different fats have the same value; and (2) the recoveries (REC) of milk fat and protein in dairy products are constant.

Caseins are the proteins that cause milk to coagulate; they form the basis of cheese production, whereas the other milk proteins remain primarily within the whey. Despite this, caseins are seldom included in selection indices because (1) the casein ratio (the ratio between caseins and total protein) is not very variable (Schopen et al., 2009); and (2) the casein and protein contents present genetic correlations close to unity (Ikonen et al., 2004; Samoré et al., 2012). However, the recovery of milk protein in curd has greater variability than the casein index (Cipolat-Gotet et al., 2013), indicating that some whey proteins can be entrapped in the curd and some caseins can escape coagulation and be lost in the whey. Furthermore, the recovery of milk fat in curd shows some variability that can significantly affect cheese yield (Fagan et al., 2007). The recovery of total solids is influenced by fat and protein recoveries, fat:protein ratio, and the lactose and mineral contents of the curd. Moreover, the recovery of different nutrients influences the recovery of milk energy in curd. Finally, although the compositions and recoveries of the different nutrients determine the total solid cheese yield, cheese yield is also influenced by the ability of the curd to retain water and its solutes.

Cheese yields and nutrient recoveries or whey losses are influenced by many factors, such as milk composition, the technological properties of the milk, the cheese-making process used, and the time and size of curd cutting (Janhøj and Qvist, 2010). However, we have no information on the heritability of these parameters or their genetic correlations with other traits.

The aims of this study were to use model cheeses from individual milk samples in a population of Brown Swiss cows to estimate the genetic parameters for different measures of percentage and daily cheese yields and curd nutrient recoveries (or whey losses), and to estimate their genetic relationships with milk yield and composition.

\section{MATERIALS AND METHODS}

\section{Animals and Milk Sampling}

Milk samples were obtained from a total of 1,167 Brown Swiss cows from 85 herds (a maximum of 15 cows per herd) located in the Alpine province of Trento (Italy); milk samples were obtained once per cow during evening milking. Within a given day, only a single herd was sampled.

The present study is part of the Cowability-Cowplus projects. Detailed descriptions of the sampling procedure may be found in Cipolat-Gotet et al. (2012) and Cecchinato et al. (2013). Briefly, the collected samples (without preservative) were immediately refrigerated at $4^{\circ} \mathrm{C}$ and transferred to the Cheese-Making Laboratory of the Department of Agronomy, Food, Natural resources, Animals and Environment (DAFNAE) of the University of Padova (Legnaro, Padova, Italy).

Data on the cows and herds were provided by the Superbrown Consortium of Bolzano and Trento (Italy), and pedigree information was supplied by the Italian Brown Swiss Cattle Breeders Association (ANARB, Verona, Italy). We included cows with phenotypic records available for the investigated traits and all known ancestors. Each sampled cow had at least 4 generations of known ancestors, and the pedigree file included 8,845 animals. The number of sires was 1,326; of these, 264 had progeny with records in the data set (each sire having between 2 and 80 daughters). 


\section{Model Cheese-Making Procedure}

All samples were processed within $20 \mathrm{~h}$ after collection. Individual milk samples were analyzed for fat, protein, and casein percentages using a MilkoScan FT6000 (Foss, Hillerød, Denmark). Somatic cell count values were obtained from the Fossomatic FC counter (Foss) and were then converted to SCS by means of logarithmic transformation (Ali and Shook, 1980). The milk $\mathrm{pH}$ values were obtained after the heating step of the cheese-making process, using a Crison Basic 25 electrode (Crison, Barcelona, Spain).

The procedure used for individual model-cheese production was based on that described by Cologna et al. (2009), which showed good repeatability. A detailed description of the modified cheese-making procedure is reported in the companion paper (Cipolat-Gotet et al., 2013) and is based on production conditions frequently adopted for production of cheese with a short ripening time. Briefly, 1,500 $\mathrm{mL}$ of milk was heated to $35^{\circ} \mathrm{C}$ in a stainless steel micro-vat, supplemented with thermophilic starter culture, mixed with rennet, and controlled for coagulation time. The resulting curd of each vat was cut, drained, shaped in wheels, pressed, salted, weighed, sampled, and analyzed. The whey collected from each vat was also weighed, sampled, and analyzed. All the processed milk samples coagulated within a standard testing time and yielded a model cheese.

\section{Trait Definitions}

All the measured traits were based on the weights (wt, g) and chemical compositions of milk and whey. The energy of the curd $(\mathrm{kJ} / \mathrm{g})$ was estimated as the difference between the energy of the milk and whey calculated according to NRC (2001). The measured traits were as follows:

(1) percentage cheese yield $\left(\mathbf{\%}_{\mathbf{C Y}} \mathbf{Y}_{\mathbf{C U R D}}\right)$ as wt of curd $\times 100 /$ wt of milk;

(2) percentage total solids (TS) cheese yield $\left(\% \mathbf{C Y}_{\text {SOLIDS }}\right.$ ) as (wt of milk TS - wt of whey TS) $\times 100 /$ wt of milk;

(3) percentage water cheese yield $\left(\mathbf{\%} \mathbf{C Y}_{\text {WATER }}\right)$ as $($ wt of milk water - wt of whey water $) \times 100 /$ wt of milk;

(4) fat recovery $\left(\mathbf{R E C}_{\mathrm{FAT}}, \%\right)$ as (wt of milk fat - wt of whey fat) $\times 100 /$ wt of milk fat;

(5) protein recovery ( $\mathbf{R E C}_{\text {PROTEIN }}, \%$ ) as (wt of milk protein - wt of whey protein $) \times 100 /$ wt of milk protein;

(6) TS recovery $\left(\mathbf{R E C}_{\text {SOLIDS }}, \%\right)$ as (wt of milk TS - wt of whey TS) $\times 100 /$ wt of milk TS;
(7) energy recovery $\left(\mathbf{R E C}_{\text {ENERGY }}, \%\right)$ as (milk energy - whey energy) $\times 100 /$ milk energy;

(8) daily cheese yield ( $\left.\mathbf{d C Y}_{\mathbf{C U R D}}, \mathbf{k g} / \mathrm{d}\right)$ as $\% \mathrm{CY}_{\mathrm{CURD}} \times$ daily milk yield of a cow (dMY, $\mathrm{kg} / \mathrm{d}) \times 0.01$

(9) daily TS cheese yield ( $\left.\mathbf{d C Y}_{\text {SoliDs}}, \mathrm{kg} / \mathrm{d}\right)$ as $\% \mathrm{CY}_{\text {SOLIDS }} \times \mathrm{dMY} \times 0.01 ;$ and

(10) daily water cheese yield $\left(\mathbf{d} \mathbf{C} \mathbf{Y}_{\text {WATER }}, \mathrm{kg} / \mathrm{d}\right)$ as $\% \mathrm{CY}_{\text {WATER }} \times \mathrm{dMY} \times 0.01$.

\section{Nongenetic Effects}

Nongenetic effects were included in the mixed models designed to estimate heritability and genetic correlations for the measures of cheese yield and nutrient recovery. These nongenetic effects were identified in preliminary analyses based on the general linear model procedure (SAS institute Inc., Cary, NC). For all traits, the model accounted for the effects of the herd sampling-processing date (85 levels), DIM of the cow (class 1: $<30$ d, class 2: 30-60 d, class 3: 61-90 d; class 4: $91-120 \mathrm{~d}$; class 5: $121-150 \mathrm{~d}$; class $6: 151-180 \mathrm{~d}$; class 7: 181-210 d; class 8: 211-240 d; class 9: 241-300 d; class 10: $>300 \mathrm{~d}$ ), the parity of the cows ( 1 to $\geq 4$ ), and vats/waterbaths (15 levels).

\section{Genetic Analysis}

Statistical inferences were based on a set of bivariate analyses that considered pairs of traits. These traits were individual cheese yields (i.e., $\% \mathrm{CY}_{\mathrm{CURD}}$, $\% \mathrm{CY}_{\text {SOLIDS }}, \% \mathrm{CY}_{\text {WATER }}$ ), nutrient recoveries (i.e., REC $_{\text {PROTEIN }}$, REC $\left._{\text {FAT }}, \mathrm{REC}_{\text {SOLIDS }}, \mathrm{REC}_{\text {ENERGY }}\right)$, single test-day milk yield and cheese production (i.e., dMY, $\mathrm{dCY}_{\mathrm{CURD}}, \mathrm{dCY}_{\text {SOLIDS }}$, and dCY $\left.\mathrm{Y}_{\text {WATER }}\right)$, milk composition (i.e., fat, protein, and casein), and SCS. Each bivariate analysis was based on the following linear mixed model:

$$
\mathbf{y}=\mathbf{X b}+\mathbf{Z}_{1} \mathbf{h}+\mathbf{Z}_{2} \mathbf{a}+\mathbf{e},
$$

where $\mathbf{y}$ is a vector of records for traits 1 and $2 ; \mathbf{X}, \mathbf{Z}_{1}$, and $\mathbf{Z}_{2}$ are appropriate incidence matrices for systematic effects in $\mathbf{b}$, herd effects in $\mathbf{h}$, and animal additive genetic effects in $\mathbf{a}$, respectively; and $\mathbf{e}$ is a vector of random residuals.

Bayesian Inference. (Co)variance components and related parameters were estimated using a Bayesian approach and Markov-chain Monte Carlo methods (Sorensen and Gianola, 2002). All traits were taken as continuous variables, and their values were assumed to be sampled from the following multivariate normal distribution (MVN):

$p(\mathbf{y} \mid \mathbf{b}, \mathbf{h}, \mathbf{a}, \mathbf{R}) \sim \operatorname{MVN}\left(\mathbf{X b}+\mathbf{Z}_{1} \mathbf{h}+\mathbf{Z}_{2} \mathbf{a}, \mathbf{I} \otimes \mathbf{R}\right)$, 
where $\mathbf{y}, \mathbf{b}, \mathbf{h}, \mathbf{a}, \mathbf{X}, \mathbf{Z}_{1}$, and $\mathbf{Z}_{2}$ are as defined above, $\mathbf{R}$ is a $2 \times 2$ matrix of residual (co)variances, and $\mathbf{I}$ is an identity matrix of appropriate order. The data were properly ordered within the vectors, and vectors a and $\mathbf{h}$ contained the effects for both traits individual by individual.

In a Bayesian setting, we assumed that:

$$
\begin{gathered}
p(\mathbf{a} \mid \mathbf{G}) \sim \operatorname{MVN}(0, \mathbf{A} \otimes \mathbf{G}) \text { and } \\
p(\mathbf{h} \mid \mathbf{H}) \sim \operatorname{MVN}(0, \mathbf{I} \otimes \mathbf{H}),
\end{gathered}
$$

where $\mathbf{G}$ is a $2 \times 2$ matrix of additive-genetic (co)variances, $\mathbf{A}$ is the numerator of the Wright's relationship matrix between individuals, $\mathbf{H}$ is a $2 \times 2$ (co)variance matrix for herd effects, and $\mathbf{I}$ is the identity matrix of the same order as the number of levels of herd effects. Flat priors were assumed for the effects in $\mathbf{b}$, as well as for $\mathbf{G}, \mathbf{H}$, and $\mathbf{R}$.

Gibbs Sampler. Marginal posterior distributions of unknown parameters were estimated performing numerical integration through the Gibbs sampler (Gelfand and Smith, 1990), as implemented in the program TM (http://snp.toulouse.inra.fr/ alegarra), to obtain auto-correlated samples from the joint posterior distributions and subsequently from the marginal posterior distributions of all unknowns in the model. The lengths of the chain and the burn-in period were assessed by visual inspection of trace plots, as well as by the diagnostic tests described by Geweke (1992) and Gelman and Rubin (1992). After a preliminary run, we decided to construct a single chain consisting of 850,000 iterations and discard the first 50,000 iterations as a very conservative burn-in. Subsequently, 1 in every 200 successive samples was retained, to store draws that were more loosely correlated. Thus, 4,000 samples were used to determine the posterior distributions of the unknown parameters. The lower and upper bounds of the highest $95 \%$ probability density regions for the parameters of interest were obtained from the estimated marginal densities. The posterior median was used as the point for all parameters. Auto-correlations between samples and estimates of Monte Carlo standard error (Geyer, 1992) were calculated. Effective sample size was evaluated using the algorithm of Geyer (1992).

Across-herd heritability $\left(h_{A H}^{2}\right)$, which is useful for the quantification of the role of genetics in a population compared with individual and common environmental sources of variation due to herds, was computed as

$$
h_{A H}^{2}=\frac{\sigma_{a}^{2}}{\sigma_{a}^{2}+\sigma_{h}^{2}+\sigma_{e}^{2}},
$$

where $\sigma_{a}^{2}, \sigma_{h}^{2}$, and $\sigma_{e}^{2}$ are additive genetic, herd-testdate, and residual variances, respectively.

Intra-herd heritability $\left(h_{I H}^{2}\right)$, which is useful for the quantification of genetic variation among individuals within herds and thus for evaluating the effectiveness of the genetic improvement of the trait, was computed as

$$
h_{I H}^{2}=\frac{\sigma_{a}^{2}}{\sigma_{a}^{2}+\sigma_{e}^{2}}
$$

where $\sigma_{a}^{2}$ and $\sigma_{e}^{2}$ are additive genetic and residual variances, respectively. Inference on additive genetic variation and heritability was based on the marginal posterior density estimated using pooled samples of all Gibbs chains obtained in multivariate analyses.

Additive genetic correlations $\left(r_{A}\right)$ were estimated as

$$
r_{A}=\frac{\sigma_{a 1, a 2}}{\sigma_{a 1} \cdot \sigma_{a 2}}
$$

where $\sigma_{a 1, a 2}$ is the additive genetic covariance between traits 1 and 2, and $\sigma_{a 1}$ and $\sigma_{a 2}$ are the additive genetic standard deviations (SD) for traits 1 and 2, respectively.

\section{RESULTS}

\section{Descriptive Statistics}

Table 1 shows descriptive statistics for the analyzed traits. The average cheese yield $\left(\% \mathrm{CY}_{\mathrm{CURD}}\right)$ obtained using the individual model-cheese production procedure was $15.0 \%$ and the coefficient of variation $(\mathbf{C V})$ was $13 \% ; \% \mathrm{CY}_{\text {SOLIDS }}$ represented slightly less than half the $\% \mathrm{CY}_{\text {CURD }}$, whereas $\% \mathrm{CY}_{\text {WATER }}$ was slightly more than half. The $\mathrm{CV}$ of $\% \mathrm{CY}_{\text {WATER }}$ was higher than that of $\% \mathrm{CY}_{\text {SOLIDS }}$ (16 and 13\%, respectively). The nutrient recoveries averaged $51.9 \%\left(\mathrm{REC}_{\text {SOLIDS }}\right)$ to $89.8 \%$ $\left(\mathrm{REC}_{\mathrm{FAT}}\right)$, whereas their CV were lower than those of the cheese yields at $3,4,7$, and $5 \%$ for $\mathrm{REC}_{\text {PRoteIN }}$, $\mathrm{REC}_{\mathrm{FAT}}, \mathrm{REC}_{\text {SOLIDS }}$, and $\mathrm{REC}_{\text {ENERGY }}$, respectively.

The milk production composition traits (fat, protein, and casein contents) and SCS (Table 1) were representative of the Italian Brown Swiss population (Samoré et al., 2007, 2012; Cecchinato et al., 2011), and individual cheese production, on average, was equal to $3.63,1.74$, and $1.88 \mathrm{~kg} / \mathrm{d}$, respectively, for $\mathrm{dCY}_{\mathrm{CURD}}, \mathrm{dCY}_{\text {SOLIDS }}$, and $\mathrm{dCY}_{\text {WATER }}$. The $\mathrm{CV}$ of these new traits were high and similar to that of dMY (31 to $34 \%$ ).

\section{Variance Components and Heritability}

Point estimates and features of the marginal posterior densities for the additive genetic, herd-test-date, 
Table 1. Descriptive statistics of individual percentage cheese yield (\%CY; weight of fresh curd, curd solids, and curd water as percentage of weight of milk processed), milk nutrient recovery (REC; protein, fat, solids, and energy of the curd as percentage of the protein, fat, solids, and energy of the milk processed), daily production (dCY; curd, curd solids, and curd water produced per cow), and milk quality traits

\begin{tabular}{|c|c|c|c|}
\hline Trait & $\begin{array}{c}\text { No. of } \\
\text { samples }\end{array}$ & Mean & $\mathrm{CV}, \%$ \\
\hline \multicolumn{4}{|c|}{ Cheese yield, \% } \\
\hline$\% \mathrm{CY}_{\mathrm{CURD}}$ & 1,162 & 14.97 & 13 \\
\hline$\% \mathrm{CY}_{\text {SOLIDS }}$ & 1,153 & 7.18 & 13 \\
\hline$\% \mathrm{CY}_{\text {WATER }}$ & 1,156 & 7.77 & 16 \\
\hline \multicolumn{4}{|c|}{ Nutrient recovery, \% } \\
\hline $\mathrm{REC}_{\text {PROTEIN }}$ & 1,158 & 78.08 & 3 \\
\hline $\mathrm{REC}_{\mathrm{FAT}}$ & 1,143 & 89.79 & 4 \\
\hline $\mathrm{REC}_{\text {SOLIDS }}$ & 1,157 & 51.88 & 7 \\
\hline REC $_{\text {ENERGY }}$ & 1,144 & 67.19 & 5 \\
\hline \multicolumn{4}{|c|}{ Production traits, $\mathrm{kg} / \mathrm{d}$} \\
\hline Milk yield & 1,153 & 24.62 & 31 \\
\hline $\mathrm{dCY} Y_{\mathrm{CURD}}$ & 1,153 & 3.63 & 32 \\
\hline $\mathrm{dCY}_{\text {SOLIDS }}$ & 1,153 & 1.74 & 33 \\
\hline $\mathrm{dCY}_{\text {WATER }}$ & 1,153 & 1.88 & 34 \\
\hline \multicolumn{4}{|c|}{ Milk quality traits } \\
\hline Fat, $\%$ & 1,163 & 4.21 & 17 \\
\hline Protein, \% & 1,163 & 3.69 & 11 \\
\hline Casein, \% & 1,163 & 2.88 & 11 \\
\hline SCS,${ }^{1}$ units & 1,163 & 2.98 & 62 \\
\hline
\end{tabular}

${ }^{1} \mathrm{SCS}=\log _{2}(\mathrm{SCC} \times 100,000)+3$.

and residual variances, as well as the across-herd and intra-herd heritabilities for the investigated traits, are reported in Table 2 . The herd-test-date variance for $\% \mathrm{CY}_{\mathrm{CURD}}$ was larger than the variances attributed to the polygenic effect, and the variability represented by the individual environmental causes of variation (within herd-test-date, parity, DIM, and laboratory vat) was higher than that related to herd-test-date. From this, the across-herd heritability $\left(h_{A H}^{2}\right)$ of $\% \mathrm{CY}_{\mathrm{CURD}}$ was equal to $18.5 \%$, whereas the within-herd heritability $\left(h_{I H}^{2}\right)$ was much higher at $26.7 \%$. Analyzing the components of $\% \mathrm{CY}_{\text {CURD }}$ (Table 2), \% $\mathrm{CY}_{\text {SOLIDS }}$ showed, as expected, lower variances than $\% \mathrm{CY}_{\mathrm{CURD}}$, but the 3 random sources of variation accounted for similar proportions of the variance, and thus the 2 traits had similar heritability estimates (20.6 and $26.3 \%$, respectively). All variances of $\% \mathrm{CY}_{\text {WATER }}$ were higher than those of $\% \mathrm{CY}_{\text {SOLIDS }}$, especially that of herd-test-date. As a consequence, $\% \mathrm{CY}_{\text {WATER }}$ yielded an $h_{A H}^{2}$ estimate (13.0\%) much lower than the $h_{I H}^{2}(22.4 \%)$, and both were lower than the corresponding estimates for $\% \mathrm{CY}_{\text {SOLIDS. }}$.

In the context of nutrient recoveries, $\mathrm{REC}_{\text {PROTEIN }}$ had very high (and similar) genetic and individual residual components, both of which were higher than the herd/ test-date source of variation (Table 2). As a consequence, $h_{A H}^{2}$ was high $(35.3 \%)$ and $h_{I H}^{2}$ was very high (49.0\%). The trait $\mathrm{REC}_{\mathrm{FAT}}$ showed an additive genetic variance similar to that of $\mathrm{REC}_{\text {PROTEIN }}$ but had higher herd-test-date and residual variances, and thus yielded much lower $h_{A H}^{2}(14.1 \%)$ and $h_{I H}^{2}(20.8 \%)$ estimates.

The overall recoveries ( $\mathrm{REC}_{\text {SOLIDS }}$ and $\mathrm{REC}_{\text {ENERGY }}$ ) showed genetic variances similar to those of the individual nutrient recoveries, herd-test-date variances intermediate with respect to the previous examined traits, and residual variances similar to those of $\mathrm{REC}_{\mathrm{FAT}}$. The resulted heritability estimates of $\mathrm{REC}_{\text {SOLIDS }}$ and $\mathrm{REC}_{\text {ENERGY }}$ were intermediate between those of the 2 individual nutrients: 21.6 and $18.4 \%$ for $h_{A H}^{2}$ and $27.4 \%$ and $23.2 \%$ for $h_{I H}^{2}$, respectively.

Figure 1 ( $\mathrm{a}$ and $\mathrm{b}$ ) clearly shows that the marginal posterior densities of the $h_{A H}^{2}$ estimates for the different cheese yields and nutrient recoveries overlap, and also that the posterior probability of heritability being greater than $10 \%$ was almost $100 \%$ for all traits except for $\% \mathrm{CY}_{\mathrm{WATER}}$ and $\mathrm{REC}_{\mathrm{FAT}}$, which were 97 and $95 \%$, respectively. As expected, the posterior probability of heritability being greater than $10 \%$ was much greater for the $h_{I H}^{2}$ estimates of all traits (data not shown).

Comparison with the heritability estimates for milk production and composition traits (Table 2) revealed that heritability estimates of the percentage cheese yields and nutrient recoveries were higher than that of milk yield and comparable with those of milk contents. The recoveries of individual nutrients (protein and fat) were more heritable than of the corresponding milk contents, and the recoveries of overall nutrients (TS and energy) yielded heritability estimates similar to those of the protein and casein contents in milk. In contrast, daily cheese yields showed heritability values similar to the daily milk yield (Table 2; Figure 1c).

\section{Phenotypic, Genetic, and Residual Correlations}

The $\% \mathrm{CY}_{\mathrm{CURD}}$ showed high phenotypic, genetic, herd, and residual correlations with its 2 components, $\% \mathrm{CY}_{\text {SOLIDS }}$ and $\% \mathrm{CY}_{\text {WATER }}$ (Table 3 ). With respect to the phenotypic and residual correlations between the 2 major cheese yield components, the retention of water in curd was moderately correlated with the retention of TS ( 0.37 and 0.31 , respectively). In contrast, these traits were much more highly correlated genetically (0.87), whereas their herd correlation was almost null.

The recovery of protein (Table 3) was totally independent with respect to phenotypic and residual correlations $(-0.02$ and -0.07 , respectively) and showed only moderate genetic relationship (0.32), whereas the correlation among herds was slightly negative. Fat recovery was moderately correlated (phenotypic, genetic, herd, and residual correlations) with both overall recoveries $\left(\mathrm{REC}_{\text {SOLIDS }}\right.$ and $\left.\mathrm{REC}_{\text {ENERGY }}\right)$. Protein recovery, in 
Table 2. Features of marginal posterior densities of additive genetic $\left(\sigma_{a}^{2}\right)$, herd/test-date $\left(\sigma_{h}^{2}\right)$, and residual $\left(\sigma_{e}^{2}\right)$ variances, and across-herd $\left(h_{A H}^{2}\right)$ and intra-herd $\left(h_{I H}^{2}\right)$ heritabilities for percentage cheese yield $(\% \mathrm{CY}$; weight of fresh curd, curd solids and curd water as percentage of weight of milk processed), milk nutrients recovery (REC; protein, fat, solids, and energy of the curd as percentage of the protein, fat, solids, and energy of the milk processed), daily production ( $\mathrm{dCY}$; curd, curd solids, and curd water produced per cow) and milk quality traits ${ }^{1}$

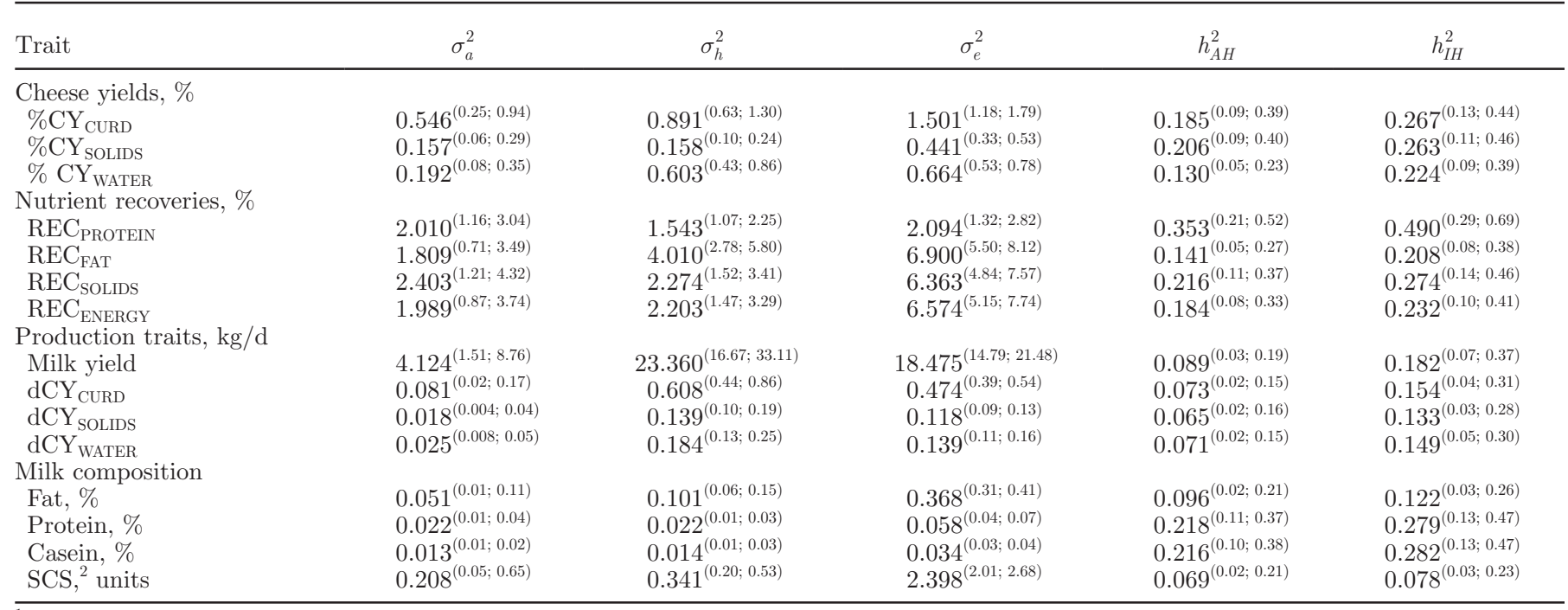

${ }^{1}$ Values are the medians of the marginal posterior densities of the parameter; bounds of the $95 \%$ high posterior density

interval are within parentheses.

${ }^{2} \mathrm{SCS}=\log _{2}(\mathrm{SCC} \times 100,000)+3$.

contrast, presented moderate positive genetic correlations with overall recoveries, low positive phenotypic and residual correlations, and null herd correlations (Table 3 ). The 2 overall recoveries were highly correlated with each other (Table 3 ).

Considering the relationships between the percentage cheese yields and nutrient recoveries (Table 4), the phenotypic, genetic, herd, and residual correlations of $\% \mathrm{CY}_{\mathrm{CURD}}$ and $\% \mathrm{CY}_{\text {SOLIDS }}$ with individual nutrient recoveries were moderately positive ( 0.22 to 0.58$)$, whereas those with the overall recoveries were high (0.54 to 0.97), with the exception of the very low herd correlation between $\mathrm{REC}_{\mathrm{FAT}}$ and \% $\mathrm{CY}_{\mathrm{SOLIDS}}$, and the null herd correlation between $\mathrm{REC}_{\text {PROTEIN }}$ and $\% \mathrm{CY}_{\text {SOLIDS }}$.

The retention of water in the curd presented low to moderate phenotypic and residual correlations ( 0.13 to 0.43 ) with all of the nutrient recoveries, moderate correlations with $\mathrm{REC}_{\text {PROTEIN }}$ and $\mathrm{REC}_{\mathrm{FAT}}(0.38$ and 0.50 , respectively), and high correlations with $\mathrm{REC}_{\text {ENERGY }}$ and $\mathrm{REC}_{\text {SOLIDS }}(0.83$ and 0.88 , respectively). Finally, herd correlations between $\% \mathrm{CY}_{\mathrm{WATER}}$ and the REC measures were low to moderate, with the exception of $\mathrm{REC}_{\mathrm{FAT}}$ (null).

The phenotypic, genetic, herd, and residual correlations of milk yield and composition and of SCS with percentage cheese yields and nutrient recoveries are shown in Table 5. Milk yield presented almost null phenotypic and residual correlations and tended to have low and unfavorable additive genetic correlations with all of the individual percentage cheese yield and nutrient recovery measures $(-0.20$ to -0.47$)$, with the exception of a low and favorable genetic correlation with REC $_{\text {PROTEIN }}(0.27)$. In contrast, herd correlations were moderate to low and positive. Milk fat and protein contents showed high (with \% $\mathrm{CY}_{\text {CURD }}$, $\% \mathrm{CY}_{\text {SOLIDS }}, \mathrm{REC}_{\text {ENERGY }}$, and $\mathrm{REC}_{\text {SOLIDS }}$ ) or low to moderate (with \% $\mathrm{CY}_{\mathrm{WATER}}, \mathrm{REC}_{\mathrm{FAT}}$, and $\mathrm{REC}_{\mathrm{PROTEIN}}$ ) positive phenotypic, herd, and residual correlations with cheese-making related traits, with the exception of the moderate negative herd relationships between milk fat and protein contents with $\mathrm{REC}_{\text {Protein. The }}$ milk contents showed very high and positive additive genetic correlations with all of the measures of percentage cheese yield, especially $\% \mathrm{CY}_{\text {SOLIDS }}(0.92$ to 0.97 ) and the recovery of total solids and energy in the curd. Fat content had low genetic correlations with $\mathrm{REC}_{\mathrm{FAT}}$ $(-0.19)$ and $\operatorname{REC}_{\text {Protein }}(0.21)$. The protein content of milk showed a positive moderate genetic correlation with $\mathrm{REC}_{\mathrm{FAT}}(0.40)$ and negligible genetic correlation with $\mathrm{REC}_{\text {PROTEIN }}(0.03)$. The milk casein content (data not shown) presented phenotypic, genetic, herd, and residual correlations with all cheese-making traits very similar to those shown by milk protein content (maximum difference 0.06).

The SCS content of milk presented negligible phenotypic, herd, and residual correlations with all cheese- 
a)

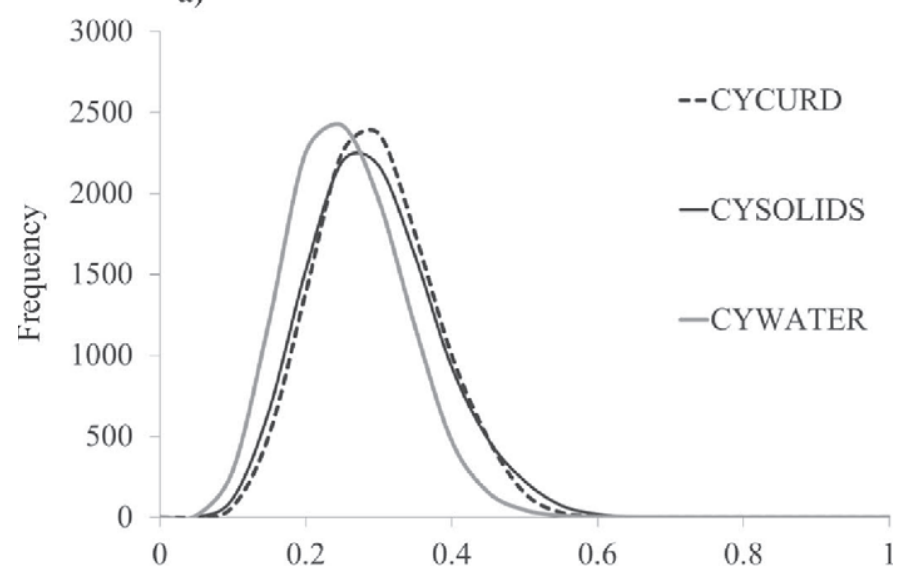

b)

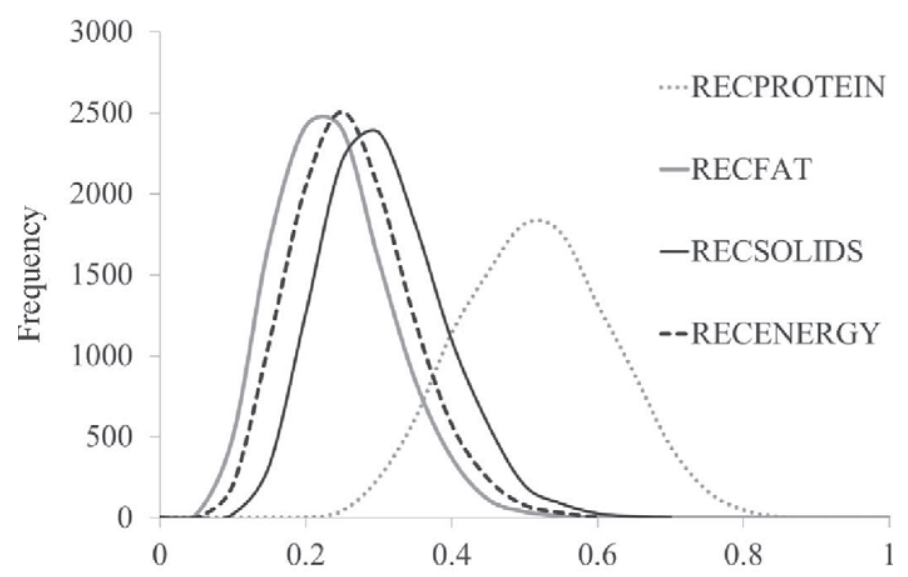

c)

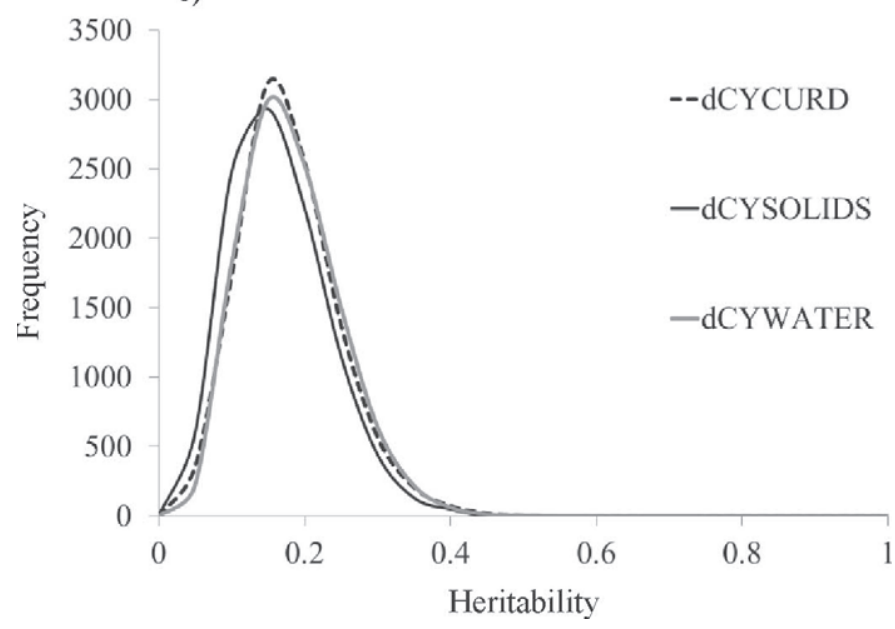

Figure 1. Marginal posterior distributions of the intra-herd heritability for measures of (a) individual cheese yield expressed as fresh curd $\left(\mathrm{CY}_{\text {CURD }}, \%\right)$, curd solids ( $\left.\mathrm{CY}_{\text {SOLIDS }}, \%\right)$, and curd water $\left(\mathrm{CY}_{\text {WATER }}\right.$, $\%$ ); and (b) the recoveries of protein $\left(\mathrm{REC}_{\mathrm{PROTEIN}}, \%\right)$, fat $\left(\mathrm{REC}_{\mathrm{FAT}}\right.$, $\%$ ), total solids $\left(\mathrm{REC}_{\text {SOLIDS }}, \%\right)$, and energy ( $\left.\mathrm{REC}_{\text {ENERGY }}, \%\right)$; (c) daily production (dCY; milk, curd, curd solids, and curd water produced per cow) and test-day milk composition. making related traits (Table 5), except for phenotypic and residual correlations with $\mathrm{REC}_{\text {PROTEIN. Overall, }}$ genetic correlations between SCS and cheese-making related traits tended to be negative, with the exception of $\mathrm{REC}_{\mathrm{FAT}}$. However, almost all estimates included zero in the $95 \%$ highest posterior density region interval.

\section{DISCUSSION}

\section{Genetic Parameters of Cheese Yield}

The percentage cheese yield from the milk of Brown Swiss cows, calculated on the basis of the weight of the curd after brining, was higher $(15.0 \%$ on average, Table 1) than estimates obtained in other breeds (VerdierMetz et al., 1998, 2001; Martin et al., 2009; Glantz et al., 2011) on cheeses ripened for a short time and produced using a procedure similar to the present study. The main reasons for this are the high fat, protein, and casein contents and the good coagulation properties (Cecchinato et al., 2011; Bittante et al., 2012) that characterize milk from Brown Swiss cows and make it particularly suited for the production of some Italian traditional cheeses that come under the Protected Designation of Origin, as defined by the European Union (De Marchi et al., 2008; Bittante et al., 2011a,b).

The heritability estimates obtained in the present study for milk yield and composition were close to those reported in previous studies in the Brown Swiss population (Samoré et al., 2007, 2012; Cecchinato et al., 2011). It is interesting to note that the heritability estimates obtained in the present study for percentage cheese yields were much higher than the corresponding estimates of daily milk yield and milk fat content, and close to the estimates obtained for milk protein content, whereas the heritability of daily cheese yield is very similar to that of daily milk yield.

To our knowledge, the present study offers the first heritability estimates of cheese yields and nutrient recoveries obtained from individual cheese-making in the bovine species. The only other heritability estimate of percentage cheese yield found in the literature comes from a laboratory test carried out on very small quantities of ewe milk $(10 \mathrm{~mL})$ that were mixed with a very high concentration of chymosin (2.4 international milkclotting units $/ \mathrm{mL}$ ) and measured after a fixed time from rennet addition $(1 \mathrm{~h})$, trough centrifugation (15 min), and draining (45 min), as described in Othmane et al. (2002a). A large data set was obtained with this procedure $(7,492$ samples from 1,119 Spanish Churra ewes), and Othmane et al. (2002b) obtained a test-day heritability estimate of individual cheese yield (corresponding to $\% \mathrm{CY}_{\mathrm{CURD}}$ of the present study) that was much lower $(8 \%)$ than that found in the present work. 
Table 3. Phenotypic $\left(r_{p}\right)$, additive genetic $\left(r_{g}\right)$, herd $\left(r_{h}\right)$, and residual $\left(r_{e}\right)$ correlations among individual percentage cheese yields $(\% \mathrm{CY}$; weight of fresh curd, curd solids, and curd water as percentage of weight of milk processed) and among nutrient recovery (REC; protein, fat, total solids, and energy of the curd as percentage of the protein, fat, total solids, and energy of the milk processed) ${ }^{1}$

\begin{tabular}{|c|c|c|c|c|}
\hline Trait & $r_{p}$ & $r_{g}$ & $r_{h}$ & $r_{e}$ \\
\hline
\end{tabular}

${ }^{1}$ Estimates are the medians of the marginal posterior density of the parameter; the lower and upper bounds of the $95 \%$ highest posterior density region (HPD95\%) are given within parentheses.

In contrast, their heritability estimates for the daily milk yield (15\%), fat content (6\%), and protein content $(23 \%)$ of ewe milk were similar to those obtained in the present study on cow milk. Based on repeated sampling of animals, those authors also estimated the heritability of lactation data (Othmane et al., 2002b) and obtained a heritability (26\%) for the milk yield of the entire lactation that was much higher than the test-day heritability obtained in the present work on cow milk. The same authors also calculated a lactation cheese yield but, unfortunately, expressed it as an average of the $\% \mathrm{CY}_{\mathrm{CURD}}$ obtained during lactation and obtained an estimate of heritability of $9 \%$, much lower than the heritability of test-day $\% \mathrm{CY}_{\mathrm{CURD}}$ found in the present study. It seems likely that the very small amount of milk used in cheese-yield estimation or their operating conditions could have caused repeatability issues, accounting for the low heritability estimate obtained for ewe milk. No quantitative measurement of cheese yield per lactation or per day (like our dCY) has been reported by Othmane et al. (2002b) or other groups.

In the present work, point estimates of genetic correlations between cheese yield and milk composition were high (Table 5); therefore, it could be argued that fat and protein explain a large proportion of the genetic variability observed in percentage cheese yield, but about one-fourth of the remainder of the genetic variance depends on other factors. The genetic correlation between test-day milk yield of the cow and percentage cheese yield of the milk was low and slightly unfavorable $(-0.29)$, even though the $95 \%$ highest posterior density region included zero. These results indicate that the correlated response of percentage cheese yield to changes in milk production, as dictated by current breeding goals of dairy cattle populations, is expected to be limited.

The major factors that affected percentage cheese yield, beyond milk composition, were the recoveries of

Table 4. Phenotypic $\left(r_{p}\right)$, additive genetic $\left(r_{g}\right)$, herd $\left(r_{h}\right)$, and residual $\left(r_{e}\right)$ correlations between individual percentage cheese yield (\%CY; weight of fresh curd, curd solids, and curd water as percentage of weight of milk processed) and milk nutrient recovery (REC; protein, fat, solids, and energy of the curd as percentage of the protein, fat, solids, and energy of the milk processed $)^{1}$

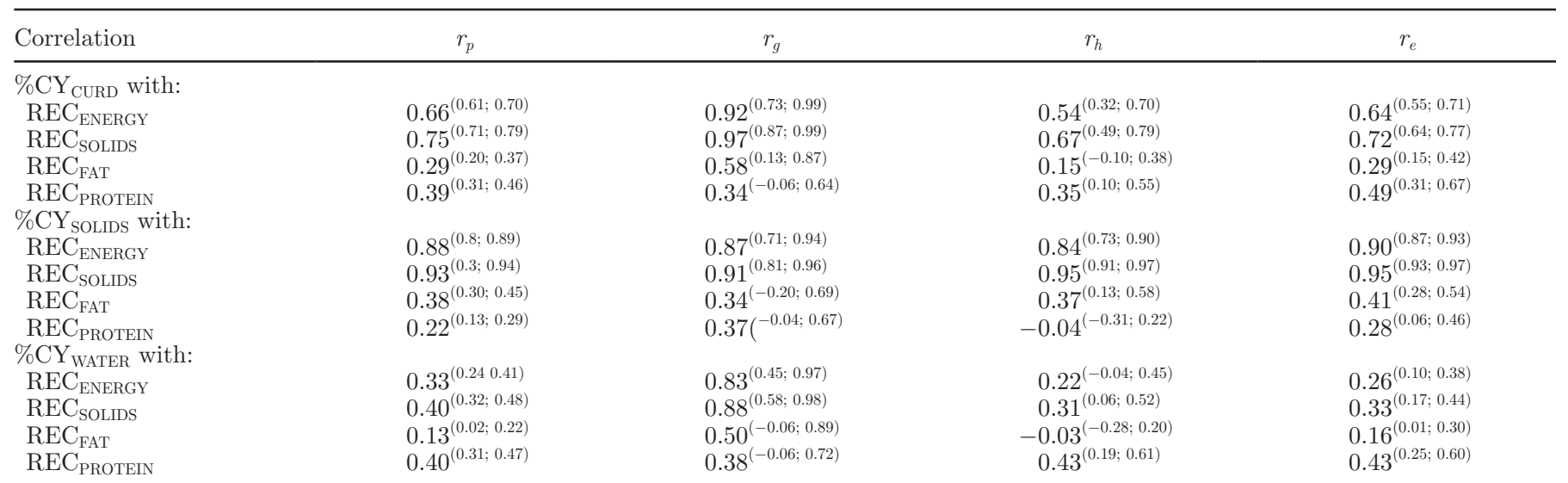

${ }^{1}$ Estimates are the medians of the marginal posterior density of the parameter; the lower and upper bounds of the $95 \%$ highest posterior density region (HPD95\%) are given within parentheses. 
Table 5. Phenotypic $\left(r_{p}\right)$, additive genetic $\left(r_{g}\right)$, herd $\left(r_{h}\right)$, and residual $\left(r_{e}\right)$ correlations between single test-day milk yield and composition and individual percentage cheese yield (\%CY; weight of fresh curd, curd solids, and curd water as percentage of weight of milk processed), and milk nutrient recovery (REC; protein, fat, solids, and energy of the curd as percentage of the protein, fat, solids, and energy of the milk processed) ${ }^{1}$

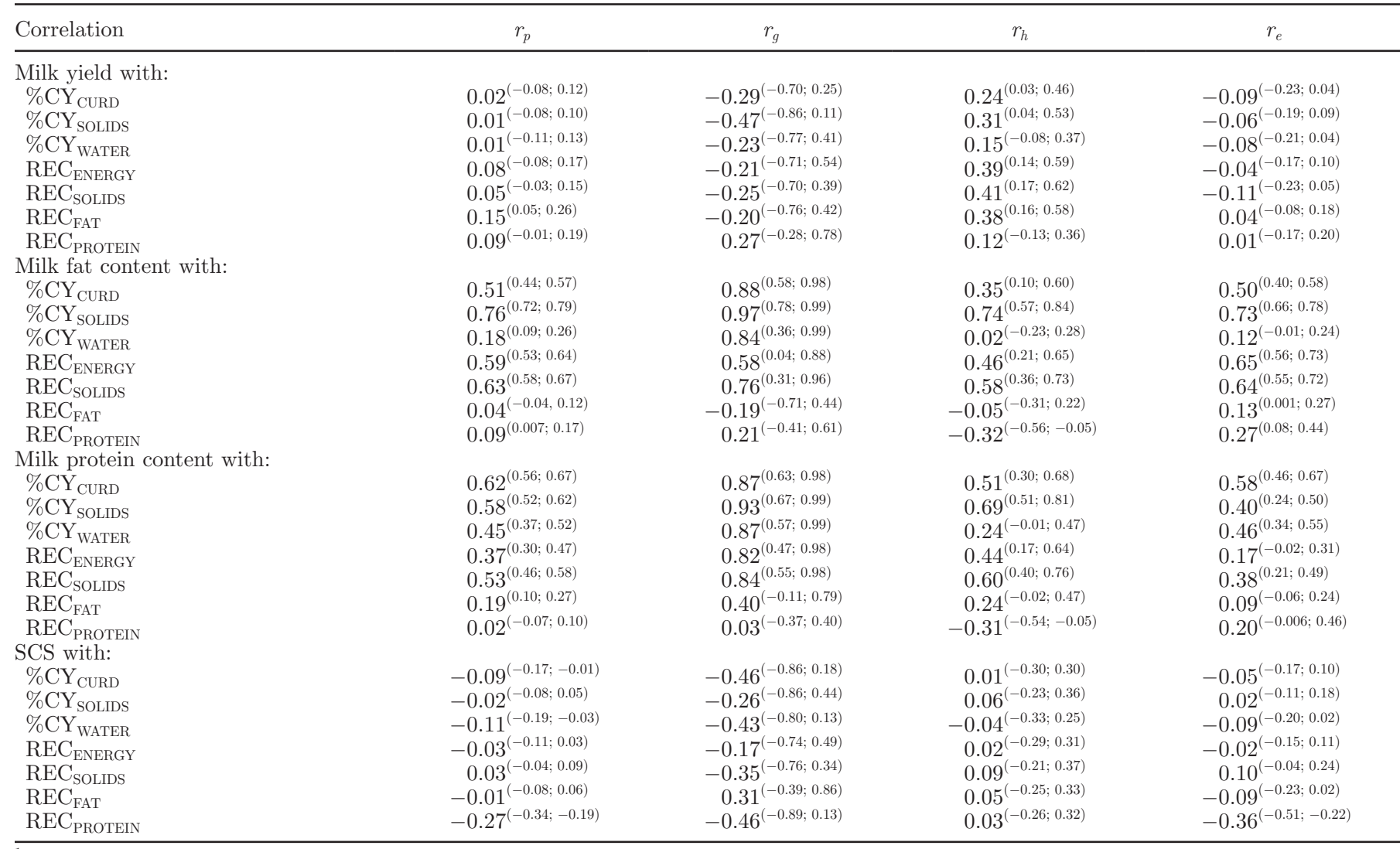

${ }^{1}$ Estimates are the medians of the marginal posterior density of the parameter; the lower and upper bounds of the $95 \%$ highest posterior density region (HPD95\%) are given within parentheses.

individual nutrients (especially protein and fat) and the ability of the curd to retain water (Fagan et al., 2007). These data cannot be obtained with the procedure described by Othmane et al. (2002a), which used a $10-\mathrm{mL}$ milk sample. In contrast, the procedure described by Cologna et al. (2009) using $500 \mathrm{~mL}$, which was improved by Cipolat-Gotet et al. (2013) for use on samples of 1,500 $\mathrm{mL}$ and applied in the present paper, allows researchers to analyze milk, whey, and curd, and to determine the complete nutrient balance between milk, whey, and cheese.

As outlined by Cipolat-Gotet et al. (2013), some studies (De Marchi et al., 2008; Martin et al., 2009) compared different breeds and found that the differences observed in average cheese yield were greater than the differences in the fat and protein (casein) contents of the milk.

\section{Genetic Contributions of TS and Water to Cheese Yield}

Similar to previous reports using similar conditions (Martin et al., 2009; Verdier-Metz et al., 2001), TS rep- resented $48 \%$ of the fresh curd after brining, meaning that water contributed slightly more to $\% \mathrm{CY}(7.8 \%$ vs. $7.2 \%$, respectively; Table 1 ). The $\% \mathrm{CY}_{\text {WATER }}$ was also characterized by a higher phenotypic CV compared with $\% \mathrm{CY}_{\text {SOLIDS }}$ (16 vs. $13 \%$, respectively).

The genetic variability of $\% \mathrm{CY}_{\text {SOLIDS }}$ was appreciable from an economic perspective, as the genetic SD was 0.40 percentage points ( $5.5 \%$ of the average). The equivalent figure for $\% \mathrm{CY}_{\text {WATER }}$ was 0.44 percentage points $(5.6 \%$ of the average). The 2 components are comparable to the genetic variation of $\% \mathrm{CY}_{\mathrm{CURD}}$ (genetic SD, 0.74 percentage points; $4.9 \%$ of the average). From Table 3, it can be seen that $\% \mathrm{CY}_{\text {SOLIDS }}$ and $\% \mathrm{CY}-$ WATER are highly correlated (0.87), and thus both are very highly correlated with their sum $(0.97$ and 0.98 , respectively). We may therefore conclude that the genetic improvement of one component will cause a large increase in the other and an even higher increase in the fresh percentage cheese yield, and a genetic increase of these traits will cause an equivalent high genetic improvement in milk TS and water retention in the curd after brining. 
The contributions of individual environmental variations to $\% \mathrm{CY}_{\text {SOLIDS }}$ and $\% \mathrm{CY}_{\text {WATER }}$ were higher than the genetic contributions, especially for $\% \mathrm{CY}_{\text {WATER }}$ (residual SD 0.66 and 0.81 percentage points, respectively). As a result, the intra-herd heritability of $\% \mathrm{CY}_{\text {SOLIDS }}$ was almost identical to that of $\% \mathrm{CY}_{\mathrm{CURD}}$ (Table 2), whereas that of $\% \mathrm{CY}_{\text {WATER }}$ was slightly lower (26.3 vs. $22.4 \%$, respectively).

A large difference was found between $\% \mathrm{CY}_{\text {SOLIDS }}$ and $\% \mathrm{CY}_{\text {WATER }}$ in the effect of herd-test-date, which showed SD of 0.40 and 0.78 percentage points, respectively. The combined effect of the genetic, residual, and herdtest-date effects on phenotypic variation explains why the $\% \mathrm{CY}_{\text {SOLIDS }}$ estimate of across-herd heritability was slightly larger than that of $\% \mathrm{CY}_{\mathrm{CURD}}$, whereas the estimate obtained for $\% \mathrm{CY}_{\text {WATER }}$ was much smaller (20.6 vs. $13.0 \%$, respectively). However, future work will be required to determine whether this relatively high effect of herd-test-date on water retention by curd was due to a moderate reproducibility of the model-cheese production procedure or to a larger effect of some environmental condition (e.g., barns, feeding, milking procedures).

In contrast to the genetic correlations, $\% \mathrm{CY}_{\text {SOLIDS }}$ and $\% \mathrm{CY}_{\text {WATER }}$ showed moderate positive phenotypic and residual correlations with each other (0.37 and 0.31 , respectively; Table 3) and low herd correlation (0.19), but high phenotypic, herd, and residual correlations with their sum (0.81 to 0.90).

The TS percentage cheese yield showed genetic correlations with the fat, protein, and casein contents of milk $(0.97,0.93$, and 0.92 , respectively), which were even greater than the high correlations for $\% \mathrm{CY}_{\mathrm{CURD}}$; conversely, the former traits showed a greater negative correlation with daily milk yield $(-0.47)$. Although these results could be expected, it was somewhat unexpected that $\% \mathrm{CY}_{\text {WATER }}$ showed genetic correlations with milk traits similar to those obtained for $\% \mathrm{CY}_{\mathrm{CURD}}$ (high and positive with milk contents and low and slightly negative with milk production). The acrossherd and intra-herd heritability estimates of $\% \mathrm{CY}_{\text {SOLIDS }}$ were both much higher than those estimated for milk fat content and almost identical to those obtained for milk protein content (Table 2).

The phenotypic, herd, and residual correlations of $\% \mathrm{CY}_{\mathrm{CURD}}$ and $\% \mathrm{CY}_{\text {SOLIDS }}$ with fat and protein content were positive and moderate to high, whereas those of $\% \mathrm{CY}_{\text {WATER }}$ were positive and moderate for protein content, and very low for fat content. Milk yield exerted an almost null phenotypic and residual correlation with all $3 \% \mathrm{CY}$ traits but a moderate positive herd correlation, which confirms that, as in the case of milk quality traits, the negative genetic correlation between milk yield and cheese yield can be compensated for by better management of animals.

It is also worth noting that although phenotypic, herd, and residual correlations between SCS and CY traits were very low, the genetic correlations tended to be negative and low to moderate (Table5).

\section{Proteins: Genetics of Curd Recovery and Whey Losses}

The coagulation and syneresis processes that characterize cheese-making are strongly dependent on milk proteins (Emmons et al., 2003). Proteins and fats are the main components of curd, and the losses of protein in whey reduce cheese yield (Hallén et al., 2010) and industry profitability, even though secondary products can be recovered from whey (e.g., ricotta cheese, dry or concentrated whey proteins).

Almost all of the selection indices used for the genetic improvement of dairy breeds around the world include the protein and fat contents of milk as predictor traits for cheese and other value-added dairy products (VanRaden, 2004). The implicit assumption is that recoveries of protein and fat are constant. However, Aleandri et al. (1989) found that curd, salted-curd, and Parmesan cheese yields were linearly related to fat content but curvilinearly related to the protein content of the vat. Our descriptive statistics (Table 1) show that the average recovery of milk protein in curd after brining was almost identical to the average casein index (78.08 vs. $78.05 \%$, respectively). However, the average recovery of milk protein in curd was characterized by an appreciable variability coefficient $(3 \%)$ in the present work. Furthermore, Cipolat-Gotet et al. (2013) showed that $\mathrm{REC}_{\text {PROTEIN }}$ is heavily influenced by herd-test-date, parity, and DIM, and previous studies showed that the recovery of casein in cheese can be substantially lower than 100\% (Bynum and Olson, 1982; Ikonen et al., 1999; Summer et al., 2003; Malacarne et al., 2006).

As shown in Table 2, an important part of this variability is of genetic origin. In fact, $\mathrm{REC}_{\text {PROTEIN }}$ had a genetic SD equal to 1.42 percentage points, which is important from the genetic and economic points of view, and higher than the genetic variability often found for casein index. The residual individual variability was of the same order as the additive genetic variability, so the intra-herd heritability of $\mathrm{REC}_{\text {PROTEIN }}$ was very high (almost 50\%; Table 2). The herd-test-date component was slightly lower than the genetic and residual variances, yielding an across-herd heritability of $35.3 \%$ for $\mathrm{REC}_{\text {PRotein. }}$

It is evident that including the protein content of milk in the selection indices for dairy breeds is use- 
ful for the indirect selection of higher cheese yields, whereas inclusion of casein content would not be likely to significantly improve the results of this indirect selection because the casein and protein contents of milk generally show a genetic correlation close to unity (Samoré et al., 2007, 2012). Furthermore, the present study found that the genetic correlations (but also the phenotypic, herd, and residual correlations) of casein with all of the individual percentage cheese yield and nutrient recovery measures were very similar to those found for CP (data not shown). Only $\mathrm{REC}_{\text {PROTEIN }}$ and $\mathrm{REC}_{\text {CASEIN }}$, which were shown to be independent of the protein and casein contents of milk, could contribute new information to support the genetic improvement of animals for increased cheese yield. Unlike the other tested measures of percentage cheese yield and nutrient content, $\mathrm{REC}_{\text {PRotein }}$ seems to be favorably correlated, from the genetic point of view, with a cow's productivity $(0.27$, with the posterior probability of being greater than zero close to $80 \%$, data not shown). As direct measurement of $\mathrm{REC}_{\text {PRотеiN }}$ is not feasible in practice, future research should focus on calibrating indirect prediction equations. Recent achievements in the improvement of milk coagulation properties have shown the potential for using medium infrared spectrometry (Dal Zotto et al., 2008; Cecchinato et al., 2009; Bittante and Cecchinato, 2013), candidate genes (Glantz et al., 2011; Cecchinato et al., 2012a,b), and genomewide approaches (Tyrisevä et al., 2008; Glantz et al., 2012). The effects of different protein fractions or their genetic variants on cheese yield have been analyzed in some phenotypic studies (Alipanah and Kalashnikova, 2007; Zambrano Burbano et al., 2010; Bonfatti et al., 2011), but their effects on $\mathrm{REC}_{\text {PROTEIN }}$ have not yet been quantified. It is also worth noting that SCS exerted an unfavorable phenotypic, genetic and residual effect on $\mathrm{REC}_{\text {PROTEIN }}$, whereas the herd correlation was null (Table 5).

\section{Fat: Genetics of Curd Recovery and Whey Losses}

Fat recovery in the curd was close to $90 \%$ on average, which can be considered normal for industrial cheesemaking (Kefford et al., 1995), and had a CV greater than that of $\mathrm{REC}_{\text {PRotein }}$ (4 vs. $3 \%$, respectively). Proteins are more important than fat in the processes of coagulation and syneresis, but the recovery of fat in the curd or its loss in the whey (which are influenced by coagulation and syneresis) are important to the final cheese yield (Fagan et al., 2007). Cipolat-Gotet et al. (2013) showed that $\mathrm{REC}_{\mathrm{FAT}}$ is heavily influenced by herd-test-date and DIM, and discussed the effects of other relevant phenotypic and technological causes of variation.
In the context of individual factors related to the genetics of the cow, Mistry et al. (2002) found that the higher Cheddar cheese yield obtained from the milk of Brown Swiss versus Holstein cows was due to superior fat recovery (94.55 vs. $90.85 \%$, respectively), whereas protein recovery was similar between the 2 breeds. Similar results were obtained by Malacarne et al. (2006) when using milk from the same breeds to produce Parmigiano-Reggiano cheese; the authors attributed this difference in fat whey loss mainly to the superior coagulation properties of Brown Swiss breed. Also, Alipanah and Kalashnikova (2007) used a smallscale trial to show that the superior cheese yield of milk obtained from cows expressing $A B$ and $B B \kappa$-casein is mainly due to differences in $\mathrm{REC}_{\text {PRotein }}$ and (especially) $\mathrm{REC}_{\mathrm{FAT}}$.

As shown in Table 2, $\mathrm{REC}_{\mathrm{FAT}}$ had an additive genetic SD similar to that of $\mathrm{REC}_{\text {PROTEIN }}$ (1.34 vs. 1.42 percentage points, respectively), but showed a much greater variability due to individual residual and herd-test-date effects. As a result, the intra-herd and across-herd heritabilities of $\mathrm{REC}_{\mathrm{FAT}}$ (20.8 and $14.1 \%$, respectively) were low to moderate and only about $40 \%$ of the corresponding estimates of $\mathrm{REC}_{\text {PRotein. Notably, the heritability }}$ estimates for $\mathrm{REC}_{\mathrm{FAT}}$ were greater than those for the fat content of milk itself (Table 2). Furthermore, RECFAT was genetically influenced by milk protein and casein contents $(0.40$ and 0.39 , respectively, both with the posterior probability of being greater than zero close to $90 \%$, data not shown) but were unfavorably related to fat content $(-0.19$; with the posterior probability of being lower than zero equal to $74 \%$, data not shown) and daily milk yield $(-0.20)$.

Interestingly, the recovery rates of the 2 major component of cheese were phenotypically independent and their genetic correlation was positive but moderate $(0.32$; Table 3$)$. In addition, the phenotypic and genetic correlations of $\mathrm{REC}_{\mathrm{PROTEIN}}$ and $\mathrm{REC}_{\mathrm{FAT}}$ with the 3 studied measures of cheese yield were all low to moderately positive ( 0.13 to 0.58 ; Table 4 ).

Similar to $\mathrm{REC}_{\mathrm{PROTEIN}}$, $\mathrm{REC}_{\mathrm{FAT}}$ could play an important role in the potential genetic improvement of cheese yield. Thus, future studies should seek means for the direct measurement (practically unfeasible) or indirect prediction (to be studied) of $\mathrm{REC}_{\mathrm{FAT}}$ through milk recording or genome-wide approaches.

\section{TS and Energy: Genetics of Curd Recovery and Whey Losses}

Although only about half of the TS present in milk is retained in cheese (Kefford et al., 1995; Verdier et al., 1995; Verdier-Metz et al., 1998), the energy content of cheese is about two-thirds that of whole milk (Table 1). 
The recoveries of TS and energy are more variable than those of their major constituents and are influenced by herd-test-date and by DIM (Cipolat-Gotet et al., 2013).

With respect to the recoveries of the major individual components of cheese, $\mathrm{REC}_{\text {SOLIDS }}$ and $\mathrm{REC}_{\text {ENERGY }}$ had similar genetic variability estimates, an intermediate herd-test-date effect, and a residual individual variance similar to that of $\mathrm{REC}_{\mathrm{FAT}}$ (Table 2). The heritability estimates were intermediate compared with those of protein and fat recoveries and similar to those of the 3 percentage cheese yields.

As expected, REC $_{\text {SOLIDS }}$ and REC $_{\text {ENERGY }}$ were strictly correlated with each other, from the phenotypic, genetic, herd, and residual points of view (Table 3). They were highly correlated with $\mathrm{REC}_{\mathrm{FAT}}(0.54$ to 0.73$)$ and moderately correlated with $\mathrm{REC}_{\text {PROTEIN }}$ (0.22 to 0.61 ), except for the null herd correlations. Their high phenotypic, genetic, herd, and residual correlations with the fat, protein, and casein contents of milk (0.37 to 0.84) reflect the dilution of the relative content of lactose and minerals (which are almost completely lost in the whey) by fat and protein (Table 5). The genetic correlations with SCS were low and unfavorable. Both $\mathrm{REC}_{\text {SOLIDS }}$ and $\mathrm{REC}_{\text {ENERGY }}$ showed high phenotypic, genetic, herd, and residual correlations (Table 4) with $\% \mathrm{CY}_{\mathrm{CURD}}$ and $\% \mathrm{CY}_{\text {SOLIDS }}(0.55$ to 0.97$)$, and high genetic correlations (0.83 and 0.88 , respectively) and moderate phenotypic, herd, and residual correlations (0.22 to 0.40$)$ with $\% \mathrm{CY}_{\text {WATER. }}$

\section{CONCLUSIONS}

We describe herein the first estimation of genetic parameters of cheese yields in a cattle population, as assessed through individual model-cheese fabrication. The heritability of percentage cheese yield was much greater than that of daily milk yield and milk fat content and similar to that of milk protein content, whereas the heritability of daily cheese yield was similar to that obtained with daily milk yield.

In almost all selection indices used around the world for the genetic improvement of cattle populations, percentage cheese yield is indirectly selected by including the major cheese components of milk: protein and fat. This implicitly assumes that protein and fat are the major determinants of cheese yield and that their recovery from milk to cheese is approximately constant and is not genetically controlled. Instead, the present study showed that fat and protein contents have high genetic correlations with percentage cheese yields, but these values were significantly lower than $100 \%$, indicating that the potential exists for further genetic improvement of cheese yields. This study also indicated the presence of phenotypic, herd, and residual variability of the protein and fat recoveries in the curd, and that the cow's genetics are important to this variability. The heritability of protein recovery was high, whereas that of fat recovery was moderate; both were greater than the heritability estimates for their respective contents in milk and milk yield, whereas their genetic correlations were low or moderate. These 2 traits are moderately correlated with each other and highly correlated with the curd recoveries of TS and energy of milk, which were highly correlated with the studied measures of percentage cheese yields. Moreover, SCS of milk was slightly unfavorably related, from the genetic point of view, with all cheese-making traits, the only exception being the fat recovery rate. Our results demonstrate the existence of an economically important genetic variability in cheese yields; this does not depend solely on the fat and protein contents of the milk and on milk yield, but rather relies on the ability of the coagulum to retain the highest possible amount of protein, fat, and water. This interesting genetic variability seems ripe for possible exploitation. However, it does not seem feasible to directly measure these aspects at the population level; therefore, further research should focus on indirect prediction (i.e., through mid-infrared spectral analysis of milk), the study of individual genes (candidate gene approach), or genome-wide scans.

\section{ACKNOWLEDGMENTS}

The authors thank the Autonomous Province of Trento (Italy) for funding the project, the project "Strengthening of the facilities supporting biotechnology research" of the Veneto Region (Italy) ("RISIB" SMUPR project 4145: Regional competitiveness and job creation; FESR 2007/2013 Action 1.1.1) for the availability of the instruments of the NIRS Food laboratory the Superbrown Consortium of Bolzano, and Trento (Trento, Italy) for the support in sampling and recording activities, the Italian Brown Swiss Cattle Breeders Association (ANARB, Verona, Italy) for providing pedigree information, and Mauro Penasa, Massimo De Marchi, Nicola Cologna, and Ilario Bazzoli (all from (DAFNAE, Department of Agronomy, Food, Natural resources, Animals and Environment, University of Padova, Italy) for their cooperation in sample collection, model cheese procedure set-up, and initial analyses of data. The authors also thank the editor and the reviewers for their useful comments.

\section{REFERENCES}

Aleandri, R., J. C. Schneider, and L. G. Buttazzoni. 1989. Evaluation of milk for cheese production based on milk characteristics and Formagraph measures. J. Dairy Sci. 72:1967-1975.

Ali, A. K. A., and G. E. Shook. 1980. An optimum transformation for somatic cell concentration in milk. J. Dairy Sci. 63:487-490. 
Alipanah, M., and L. A. Kalashnikova. 2007. Influence of k-casein genetic variant on cheese making ability. J. Anim. Vet. Adv. $6: 855-857$.

Bittante, G., and A. Cecchinato. 2013. Genetic analysis of the Fouriertransform infrared spectra of bovine milk with emphasis on individual wavelengths related to specific chemical bonds. J. Dairy Sci. 96:5991-6006. http://dx.doi.org/10.3168/jds.2013-6583.

Bittante, G., A. Cecchinato, N. Cologna, M. Penasa, F. Tiezzi, and M. De Marchi. 2011a. Factors affecting the incidence of first-quality wheels of Trentingrana cheese. J. Dairy Sci. 94:3700-3707.

Bittante, G., N. Cologna, A. Cecchinato, M. De Marchi, M. Penasa, F. Tiezzi, I. Endrizzi, and F. Gasperi. 2011b. Monitoring of sensory attributes used in the quality payment system of Trentingrana cheese. J. Dairy Sci. 94:5699-5709.

Bittante, G., M. Penasa, and A. Cecchinato. 2012. Invited review: Genetics and modeling of milk coagulation properties. J. Dairy Sci. 95:6843-6870

Bonfatti, V., A. Cecchinato, G. Di Martino, M. De Marchi, L. Gallo, and P. Carnier. 2011. Effect of $\kappa$-casein B relative content in bulk milk k-casein on Montasio, Asiago, and Caciotta cheese yield using milk of similar protein composition. J. Dairy Sci. 94:602-613.

Bynum, D. G., and N. F. Olson. 1982. Influence of curd firmness at cutting on Cheddar cheese yield and recovery of milk constituents. J. Dairy Sci. 65:2281-2290.

Cecchinato, A., C. Cipolat-Gotet, J. Casellas, M. Penasa, A. Rossoni, and G. Bittante. 2013. Genetic analysis of rennet coagulation time, curd-firming rate, and curd firmness assessed on an extended testing period using mechanical and near-infrared instruments. J. Dairy Sci. 96:50-62.

Cecchinato, A., M. De Marchi, L. Gallo, G. Bittante, and P. Carnier 2009. Mid-infrared spectroscopy predictions as indicator traits in breeding programs for enhanced coagulation properties of milk. J. Dairy Sci. 92:5304-5313.

Cecchinato, A., M. Penasa, M. De Marchi, L. Gallo, G. Bittante, and P. Carnier. 2011. Genetic parameters of coagulation properties, milk yield, quality, and acidity estimated using coagulating and noncoagulating milk information in Brown Swiss and HolsteinFriesian cows. J. Dairy Sci. 94:4214-4219.

Cecchinato, A., C. Ribeca, A. Maurmayr, M. Penasa, M. De Marchi, N. P. P. Macciotta, M. Mele, P. Secchiari, G. Pagnacco, and G. Bittante. 2012a. Short communication: Effects of $\beta$-lactoglobulin, stearoyl-coenzyme A desaturase 1 , and sterol regulatory element binding protein gene allelic variants on milk production, composition, acidity, and coagulation properties of Brown Swiss cows. J. Dairy Sci. 95:450-454.

Cecchinato, A., C. Ribeca, M. Penasa, C. Cipolat-Gotet, M. De Marchi, A. Maurmayr, and G. Bittante. 2012b. Associations between single nucleotide polymorphisms in multiple candidate genes on milk yield, composition, coagulation properties and individual cheese yield in Brown Swiss cows. J. Dairy Sci. 95(Suppl. 2):402. (Abstr.)

Cipolat-Gotet, C., A. Cecchinato, M. De Marchi, and G. Bittante, 2013. Factors affecting variation of different measures of cheese yield and milk nutrient recovery from an individual model cheesemanufacturing process. J. Dairy Sci. 96:7952-7965. 10.3168/ jds.2013-6516.

Cipolat-Gotet, C., A. Cecchinato, M. De Marchi, M. Penasa, and G. Bittante. 2012. Comparison between mechanical and near-infrared optical methods for assessing coagulation properties of bovine milk. J. Dairy Sci. 95:6806-6819.

Cologna, N., R. Dal Zotto, M. Penasa, L. Gallo, and G. Bittante. 2009. A laboratory micro-manufacturing method for assessing individual cheese yield. Ital. J. Anim. Sci. 8(Suppl. 2):393-395.

Dal Zotto, R., M. De Marchi, A. Cecchinato, M. Penasa, M. Cassandro, P. Carnier, L. Gallo, and G. Bittante. 2008. Reproducibility and repeatability of measures of milk coagulation properties and predictive ability of mid-infrared reflectance spectroscopy. J. Dairy Sci. 91:4103-4112.

De Marchi, M., G. Bittante, R. Dal Zotto, C. Dalvit, and M. Cassandro. 2008. Effect of Holstein Friesian and Brown Swiss breeds on quality of milk and cheese. J. Dairy Sci. 91:4092-4102.
Emmons, D. B. 1993. Economic importance of cheese yield. Pages 10-11 in Factors Affecting the Yield of Cheese. Special Issue 9301. International Dairy Federation, Brussels, Belgium.

Emmons, D. B., C. Dubé, and H. W. Modler. 2003. Transfer of protein from milk to cheese. J. Dairy Sci. 86:469-485.

Fagan, C. C., M. Castillo, F. A. Payne, C. P. O'Donnell, and D. J. O'Callaghan. 2007. Effect of cutting time, temperature, and calcium on curd moisture, whey fat losses, and curd yield by response surface methodology. J. Dairy Sci. 90:4499-4512.

Gelfand, A., and A. F. M. Smith. 1990. Sampling based approaches to calculating marginal densities. J. Am. Stat. Assoc. 85:398-409.

Gelman, A., and D. B. Rubin. 1992. Inference from iterative simulation using multiple sequences. Stat. Sci. 7:457-511.

Geweke, J. 1992. Evaluating the accuracy of sampling-based approaches to the calculation of posterior moments (with discussion). Pages 164-193 in Bayesian Statistics. J. O. Berger, J. M. Bernardo, A. P. Dawid, and A. F. M. Smith, ed. Oxford University Press, Oxford, UK.

Geyer, C. J. 1992. Practical Markov chain Monte Carlo. Stat. Sci. $7: 473-483$.

Glantz, M., H. Lindmark Månsson, and M. Paulsson. 2012. Genomic selection in relation to bovine milk composition and processability. J. Dairy Res. 79:53-59.

Glantz, M., H. Lindmark Månsson, H. Stålhammar, and M. Paulsson. 2011. Effect of polymorphisms in the leptin, leptin receptor, and acyl-coenzyme A:diacylglycerol acyltransferase 1 (DGAT1) genes and genetic polymorphism of milk proteins on cheese characteristics. J. Dairy Sci. 94:3295-3304.

Hallén, E., A. Lundén, T. Allmere, and A. Andrén. 2010. Casein retention in curd and loss of casein into whey at chymosin-induced coagulation of milk. J. Dairy Res. 77:71-76.

Ikonen, T., S. Morri, A.-M. Tyrisevä, O. Ruottinen, and M. Ojala. 2004. Genetic and phenotypic correlations between milk coagulation properties, milk production traits, somatic cell count, casein content, and pH of milk. J. Dairy Sci. 87:458-467.

Ikonen, T., O. Ruottinen, E.-L. Syväoja, K. Saarinen, E. Pahkala, an M. Ojala. 1999. Effect of milk coagulation properties of herd bulk milks on yield and composition of Emmental cheese. Agric. Food Sci. Finl. 8:411-422.

International Dairy Federation. 2011. The World Dairy Situation. Bulletin 451/2011. International Dairy Federation, Brussels, Belgium.

Janh $ø$ j, T., and K. B. Qvist. 2010. The formation of cheese curd. Pages 130-165 in Technology of Cheesemaking. B. A. Law, and A. Y. Tamime, ed. Wiley-Blackwell, Ames, IA.

Kefford, B., M. P. Christian, B. J. Sutherland, J. J. Mayes, and C. Grainger. 1995. Seasonal influences on Cheddar cheese manufacture: Influence of diet quality and stage of lactation. J. Dairy Res. 62:529-537.

Malacarne, M., A. Summer, E. Fossa, P. Formaggioni, P. Franceschi, M. Pecorari, and P. Mariani. 2006. Composition, coagulation properties and Parmigiano-Reggiano cheese yield of Italian Brown and Italian Friesian herd milks. J. Dairy Res. 73:171-177.

Martin, B., D. Pomies, P. Pradel, I. Verdier-Metz, and B. Remond. 2009. Yield and sensory properties of cheese made with milk from Holstein or Montbeliarde cows milked twice or once daily. J. Dairy Sci. 92:4730-4737.

Miglior, F., B. L. Muir, and B. J. Van Doormaal. 2005. Selection indices in Holstein cattle of various countries. J. Dairy Sci. 88:12551263.

Mistry, V. V., M. J. Brouk, K. M. Kaperson, and E. Martin. 2002. Cheddar cheese from milk of Holstein and Brown Swiss cows. Milchwissenschaft 57:19-23.

NRC. 2001 Nutrient Requirements of Dairy Cattle. 7th rev. ed. Natl. Acad. Press, Washington, DC.

Othmane, M. H., J. A. Carriedo, L. F. de la Fuente Crespo, and F. San Primitivo. 2002a. An individual laboratory cheese-making method for selection in dairy ewes. Small Rumin. Res. 45:67-73.

Othmane, M. H., J. A. Carriedo, F. San Primitivo, and L. F. De La Fuente. 2002b. Genetic parameters for lactation traits of milking ewes: Protein content and composition, fat, somatic cells and individual laboratory cheese yield. Genet. Sel. Evol. 34:581-596. 
Rosati, A., and L. D. Van Vleck. 2002. Estimation of genetic parameters for milk, fat, protein and mozzarella cheese production for the Italian river buffalo Bubalus bubalis population. Livest. Prod. Sci. 74:185-190.

Samoré, A. B., F. Canavesi, A. Rossoni, and A. Bagnato. 2012. Genetics of casein content in Brown Swiss and Italian Holstein dairy cattle breeds. Ital. J. Anim. Sci. 11:e36.

Samoré, A. B., C. Romani, A. Rossoni, E. Frigo, O. Pedron, and A. Bagnato. 2007. Genetic parameters for casein and urea content in the Italian Brown Swiss dairy cattle. Ital. J. Anim. Sci. 6(Suppl.1):201-203.

Schopen, G. C. B., J. M. L. Heck, H. Bovenhuis, M. H. P. W. Visker, H. J. F. van Valenberg, and J. A. M. van Arendonk. 2009. Genetic parameters for major milk proteins in Dutch Holstein-Friesians. J. Dairy Sci. 92:1182-1191.

Sorensen, D., and D. Gianola. 2002. Likelihood, Bayesian, and MCMC Methods in Quantitative Genetics. Springer-Verlag, New York, NY.

Summer, A., P. Franceschi, A. Bollini, P. Formaggioni, F. Tosi, and P. Mariani. 2003. Seasonal variations of milk characteristics and cheesemaking losses in the manufacture of Parmigiano-Reggiano cheese. Vet. Res. Commun. 27(Suppl. 1):663-666.

Tyrisevä, A.-M., K. Elo, A. Kuusipuro, V. Vilva, I. Jänönen, H. Karjalainen, T. Ikonen, and M. Ojala. 2008. Chromosomal regions underlying non-coagulation of milk in Finnish Ayrshire cows. Genetics 180:1211-1220.

VanRaden, P. M. 2004. Invited review: Selection on net merit to improve lifetime profit. J. Dairy Sci. 87:3125-3131.

Verdier, I., J. B. Coulon, P. Pradel, and J. L. Berdaguè. 1995. Effect of forage type and cow breed on the characteristics of matured SaintNectaire cheeses. Lait 75:523-533.

Verdier-Metz, I., J. B. Coulon, and P. Pradel. 2001. Relationship between milk fat and protein contents and cheese yield. Anim. Res. 50:365-371.

Verdier-Metz, I., J. B. Coulon, P. Pradel, C. Viallon, and J. L. Berdaguè. 1998. Effect of forage conservation (hay or silage) and cow breed on the coagulation properties of milk and on the characteristics of ripened cheese. J. Dairy Res. 65:9-21.

Weigel, D. J., B. G. Cassel, and R. E. Pearson. 1997. Prediction of transmitting abilities for productive life and lifetime profitability from production, somatic cell count, and type traits in milk markets for fluid milk and cheese. J. Dairy Sci. 80:1398-1405.

Zambrano Burbano, G. L., Y. M. Eraso Cabrera, C. E. Solarte Portilla and C. Y. Rosero Galindo. 2010. Kappa casein genotypes and curd yield in Holstein cows. Rev. Colomb. Cienc. Pecu. 23:422-428. 